\title{
Encapsulating the delivery of affordable housing: An overview of Malaysian practice
}

\author{
Nor Baizura Jamaluddin ${ }^{1, a}$, Yusfida Ayu Abdullah² and Hazlina Hamdan² \\ ${ }^{1}$ Centre of Postgraduate Studies, Faculty of Architecture, Planning and Surveying, Universiti Teknologi MARA, 40450 Shah Alam, Malaysia \\ ${ }^{2}$ Centre of Studies for Town and Regional Planning, Faculty of Architecture, Planning and Surveying, Universiti Teknologi MARA, 40450 \\ Shah Alam, Malaysia
}

\begin{abstract}
Urban population increases much faster than other geographical areas and this brings huge challenges to Malaysian government especially those responsible for the provision of housing. Moreover, the rise of living cost and pressure towards the current economic situation had inevitably led to huge demands for affordable housing. Thus, affordability and inaccessibility of people in owning a house has become one of the major issues in Malaysia. These issues are not only faced by the low-income group but mostly experienced by urban dwellers including the middleincome group whom are not eligible to apply for low-cost housing delivered by the government, yet cannot afford to buy a house. Hence, the Malaysian government had therefore established the Perumahan Rakyat 1 Malaysia (PR1MA) as the catalyst in providing adequate, quality and affordable houses. Furthermore, the Syarikat Perumahan Negara Berhad (SPNB) and the state governments also play their big role in providing affordable house at the state level. In trying to ensure smooth delivery of affordable housing, a systematic approach is required. This paper intends to examine the delivery of affordable housing in Malaysia. The objective was to assess the parties involved, and the various stages of the process. The methodology adopted for this study includes in-depth interviews with affordable housing agencies. Investigation showed that the major problem relates to a mismatch in the delivery of affordable housing. Moreover, the political and economic aspects, as well as the organization situation had also influenced the inefficiency of affordable housing delivery system. Additionally, the significant of this paper is expected to formulate an improved strategy and guidance in delivery system, thus ensuring that the method of practice is applicable throughout the country.
\end{abstract}

\section{Introduction}

This paper presents the results of an initial study on affordable housing in Malaysia. As determined by the National Housing Department [1], affordable house should be sold below RM300, 000 while the buyers are the households with income of RM5,000 and below. Owning a house is a dream to many especially to those who had just begun to start a family life. However, buying a house is not quite a straightforward thing and not every person can afford one. Many people, from a youth who is starting a new career and family, or those living in urban areas including from the middle-income group are affected by this difficulty [2]. Moreover, due to urbanization process, the development and expansion of major cities affects the economy of the nation [3]. In Malaysia, most of the population nowadays had migrated and lived in urban areas and that brings huge challenges towards the provision of affordable housing [4]. This was reported in the $11^{\text {th }}$ Malaysia Plan, whereby, the demand and supply gap of affordable housing still exist due to the socioeconomic change, urbanization and evolving population structures [5]. Additionally, it also reports the inadequate supply of affordable housing particularly for the middle-income households especially in the urban areas, increasing of house price in major cities and the lack of integrated planning and implementation [5].

Affordable housing has been a much debated subject in the most recent years especially in a developing country like Malaysia. Although many issues had been resolved, the country still encounters problems and this had brought various perceptions towards the development of affordable housing. The main issue is the adequacy, affordability, and inaccessibility of homeownership, and sadly, these have remained as a continuing issue even though there appeared to be plenty of housing stock to accommodate every family [6, 7]. Besides affordability and housing price, Malaysia is also facing the issue of housing delivery system $[8,1]$. In the $11^{\text {th }}$ Malaysia Plan, housing delivery remained as an important issue mentioning the lack of integration and coordination which led to the failure to meet the targets and the mismatched in delivering affordable housing [5]. It was claimed that there were many agencies involved under multiple roofs causing a duplication of duties $[8,9,6]$ and the mistake of targets with high inclusion error, sublet, or rent seeker [8]. Moreover, there appeared to be disparity on the supply and demand especially in terms of the

\footnotetext{
a Nor Baizura Jamaluddin: norbaizurajamaluddin@gmail.com
} 
location factor and the integration with public transportation $[8,10,11]$. The constraints during the planning approval process when submitting to the planning authorities or land offices, in terms of conversion of land use category, duration upon getting planning approval, and non-compliance with development plan [11]. The delivery procedures was claimed to be very tedious and time-consuming, causing it to slow down the process [12]. Meanwhile, previous studies discovered that access to mortgage and finance is one of the difficulties faced by the house buyers as it is apparent that most of the lower and middle-income people are facing with financial complexity [11], and those without fix income are obviously badly affected [9]. It is not just the commitment for loan but also the struggle to save and pay for deposits [6].

Realising these unfortunate conditions, the government performs various efforts in trying to assist the lower and middle-income groups with the provision of affordable housing as top priority. In Malaysia, housing provision is the responsibility of both public and private sectors. Private developers focus on selling medium and high cost house, whilst the government is responsible in providing houses for the low-income group. In spite of this, the situation has now changed. Other than this basic role, the government puts a lot of effort in ensuring all income groups have an equal chance in possessing a house. Throughout the $10^{\text {th }}$ Malaysia Plan (RMK-10), various public affordable housing programs were implemented. The government encourages public private partnership in housing development and therefore, private sector such as developers has now contributed in the provision. In addition, the government now also focuses in delivering low cost houses for the low-income group as well the affordable house for the middle-income group especially in the urban areas. In general, housing delivery is a system to complete and deliver housing units to the house buyers. It comprises of a process and key players involved in the housing process [12].

In order to successfully deliver affordable house to the citizens, it should consists of a system that is practiced by each agency. Through the system, the role of the parties involved and the process undertaken can be the indicators in measuring the effectiveness in delivering affordable houses. Based on the housing industry perspective, a delivery system forms one of the cornerstones of customer satisfaction [13]. Through the Vision 2020, as put forward by the forth Prime Minister of Malaysia, Tun Dr Mahathir Mohamad, in order to accomplish Vision 2020 in terms of house ownership is through "operative housing delivery system" [14].

Based on those initial background and issues discussed, this paper, therefore, aims to examine the present delivery system of affordable housing in Malaysia. The paper will review the current practice of affordable housing delivery process, the various parties involved and the issues encountered. Thereafter, it will recommend further potential study on the topic.

\section{Research Methodology}

This research paper employs the multiple case study design. It applies the qualitative method as it deals greatly with policies and implementation procedures. Its emphasis is on the various affordable housing providers in Malaysia. The main idea is to evaluate the variation of roles and practice. The main focus is by means of reviewing the existing literature. However, based on previous studies $[15,16,17]$ this study also adopts the qualitative approach by interviewing the specific agencies. As Khalaf [15] suggests, the qualitative method allows interviewees to freely answer the question concerning their views. And, because of that, the findings from the interviews will complement the literature review. For those reasons, this study had selected the three distinctive affordable housing providers, namely 1 Malaysia's People Housing Program or Syarikat Perumahan Rakyat 1 Malaysia (PR1MA), Syarikat Perumahan Negara Berhad (SPNB), and the Selangor Housing and Properties Board for Rumah Selangorku. However, drawing back from the earlier discussion on affordability, this study will only focuses on the potential buyers of the middle-income group. It had selected the State of Selangor, based on its associated features including its highly dense population in urban area. According to Selangor Department of Town and Regional Planning [18], 83\% of the population in Klang Valley are the citizens of Selangor. Selangor is an urbanised state in the Peninsular Malaysia hence faces the issue of migration and increasing demands for affordable housing, as well as the challenges of living cost. Besides the three housing providers, the study had included the National Housing Department and the Selangor Town and Country Planning Department given that they are directly involved in the process. This preliminary investigation had therefore involved ten participants and interviews were conducted among professional officers from PR1MA and SPNB as the main providers of affordable housing, officers from the Selangor Housing and Properties Board as the agency in providing affordable house throughout the state, a town planner from the Selangor Department of Town and Regional Planning, and officers from the National Housing Department from various disciplines. The following work will encompass a questionnaire survey, which is planned for the end-users. It is anticipated that this piece of work will unveils the functioning and limitation of the delivery system, thus providing a better understanding of the current practice and what can be done to enhance the delivery system. The study method is illustrated in Figure 1 below. 


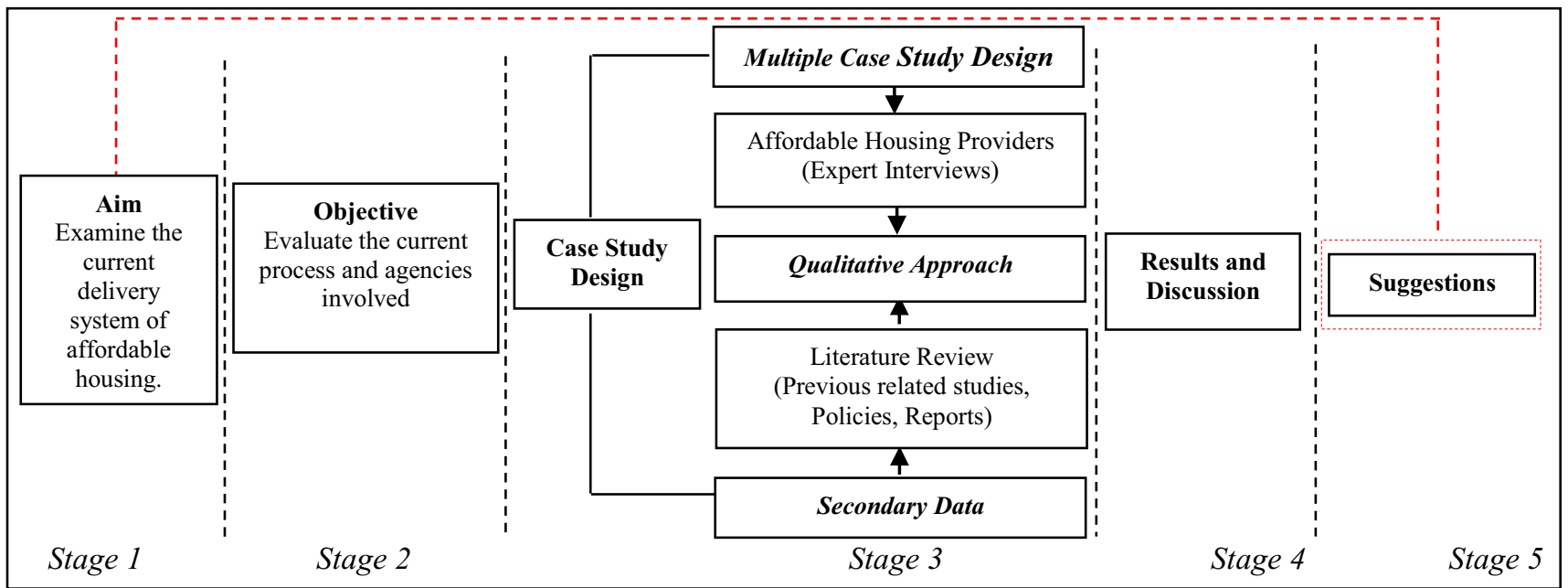

Figure 1: Research Approach

\section{Affordable Housing Development}

Since the $1^{\text {st }}$ Malaysia Plan, the major concern has been on the development of low cost housing to meet the needs of the low-income group [19-25]. During the $9^{\text {th }}$ Malaysia Plan, affordability became the main attention. Later, during the $10^{\text {th }}$ Malaysia Plan the concentration had shifted to affordable housing, and now, in the latest $11^{\text {th }}$ Malaysia Plan the focus is on the development of affordable housing. Basically, affordable housing through public housing programs is delivered at all government levels. However, each tier has established specific agency based on the particular purpose to address certain group as shown in Table 1 below.

Table 1. The main affordable house provider and the programs implemented

\begin{tabular}{|c|c|c|c|c|}
\hline Agency & Program & Purpose & $\begin{array}{l}\text { Level of } \\
\text { Income }\end{array}$ & $\begin{array}{l}\text { House } \\
\text { Prices }\end{array}$ \\
\hline $\begin{array}{l}\text { PR1MA } \\
\text { Corp. }\end{array}$ & $\begin{array}{l}\text { Perumah- } \\
\text { an Rakyat } \\
\text { 1Malaysia }\end{array}$ & $\begin{array}{l}\text { For } \\
\text { middle- } \\
\text { income } \\
\text { group }\end{array}$ & $\begin{array}{l}\text { RM2,500- } \\
\text { RM10,000 }\end{array}$ & $\begin{array}{l}\text { RM100,000- } \\
\text { RM400,000 }\end{array}$ \\
\hline SPNB & $\begin{array}{l}\text { Rumah } \\
\text { Mampu } \\
\text { Milik }\end{array}$ & $\begin{array}{l}\text { For low } \\
\text { and } \\
\text { middle- } \\
\text { income } \\
\text { group }\end{array}$ & $\begin{array}{l}\text { RM2,000- } \\
\text { RM10,000 }\end{array}$ & $\begin{array}{l}\text { RM42,000- } \\
\text { RM250,000 }\end{array}$ \\
\hline $\begin{array}{l}\text { LPHS } \\
\text { (SEDC } \\
\text { and } \\
\text { Private } \\
\text { Sectors) }\end{array}$ & $\begin{array}{l}\text { Rumah } \\
\text { Selangor- } \\
\text { ku }\end{array}$ & $\begin{array}{l}\text { For low } \\
\text { and } \\
\text { middle- } \\
\text { income } \\
\text { group }\end{array}$ & $\begin{array}{l}\text { RM3,000- } \\
\text { RM10,000 }\end{array}$ & $\begin{array}{l}\text { RM3,000- } \\
\text { RM10,000 }\end{array}$ \\
\hline
\end{tabular}

At the federal level, the National Housing Department (NHD) is involved directly in formulating the policy, laws, regulations, and governing housing especially for the private sector [26]. Moreover, other than policy making and enforcement of the related laws and regulations, the federal government has a function in processing the licenses for housing development project, control and monitor housing projects, and build more low cost and public housing programs [26]. In terms of affordable housing development, NHD had introduced My Home Scheme as one of the approaches for federal government to encourage more participation from private sectors in providing affordable house [28]. The government provides a subsidy of up to RM30,000 per unit to private developers to enable first-time buyers with a monthly household income of RM3,000 to own a house [28]. Through this scheme, the incentives offered by the federal government can be beneficial to private developers and mostly house buyers.

Meanwhile, PR1MA Corporation is the major agency responsible in providing affordable house for the middleincome group in urban areas. The organisation was established under the PR1MA Act 2012. Household income between RM2,500 until RM10,000 are categorised as the middle-income group while affordable houses offered by PR1MA are within the range of RM100,000 until RM400,000 depending on the location, type and size of house. Moreover, PR1MA houses are sold at $20 \%$ lower than the average market price, built and located at transit oriented development area. Through PR1MA, the government wants to encourage the young generation who had just starting their careers and enable them to own a house at an affordable price. PR1MA targets 200,000 units of affordable house by the year 2018 [29]. In 2015, PR1MA Corporation approved 119,933 homes for development nationwide, and 18,400 units are under construction [8]. Currently, most of the PR1MA projects have been launched. Part of that has been fully completed and occupied while the rest will be launched afterwards. Moreover, PRIMA had also introduced the Rent-to-Own Scheme to assist PR1MA house buyers [29].

Other than PR1MA, Syarikat Perumahan Negara (SPNB) also has similar responsibilities in providing affordable house to the public. The Rumah Mampu Milik Programme (RMMP) is implemented by SPNB aiming to provide affordable house across the country. Affordable housing provided by SPNB is divided into three categories; low cost house, low-medium cost house, and medium cost house [30]. To address the middle-income 
group, SPNB builds the Rumah Idaman Rakyat (RIR). It was the government's initiative and the focus is to provide affordable house to the first house buyers who are facing the dilemma of middle-income group. The properties are provided specifically for those with an income below than RM7,500 and monthly household less than RM10,000 [31]. The price for affordable house provided by SPNB is below RM250, 000 [31]. At the state level, affordable house are delivered through two main agencies; (i) Selangor Housing and Property Board (LPHS); and (ii) State Economic Development Corporation (SEDC). LPHS had delivered many affordable houses before, and during 2010, LPHS has started to provide affordable housing in Selangor with a new name called the Rumah Selangorku. Moreover, LPHS also came out with Dasar Rumah Selangorku in 2014 in which the policy will be guidance to LPHS itself and private developers involved in providing the Rumah Selangorku [32]. LPHS, however, plays an important role in policy making, housing supply, regulation, and construction [8]. Private developers are also encouraged to be involved in the development of Rumah Selangorku under the LPHS's regulation. The price for one unit of Rumah Selangorku is RM 42,000 to RM250, 000 depending on the type, area, location, and other facilities provided [8, 32]. The price range starts from household income of RM3,000 till RM8,000 [32]. Nevertheless, according to the proposed 2016 Budget, the range of household income has been increased to RM10,000 for eligibility to apply for an affordable house from the Selangor State Government [8]. The state government targets to provide 35,000 units by 2018 either from LPHS or other private developers. In addition, other than LPHS, the SEDC also known as Perbadanan Kemajuan Negeri Selangor (PKNS) contributes in assisting the state government in the provision. Affordable housing project implemented by PKNS is subjected under the Selangor Affordable Housing Policies in which the developers like PKNS must comply with this policy. Until October of $2015,30,950$ units has been approved in which 1,774 houses had been completed, while 4,782 units were under construction, and 24,304 units were approved by the Members of State [5].

\section{Actors in the Delivery Process}

In housing delivery system, there is a list of actors involved throughout the whole process. Each of them has their own role and function to ensure the housing development can be successfully implemented [14, 33]. The government has its jurisdiction in approving the procedures and its machinery, and therefore, involves at every stage of that process. The commitment of the federal government can be seen through the establishment of NHD. The government is responsible in formulating polices regarding housing provision [33] and the application of policies at the lower government level [12]. In the delivery system, any housing development had to acquire a licence and permission from NHD [12]. Meanwhile, the state government is usually responsible in policy making at the state level and delivering affordable housing programs based on the specification established by the state government. State government is also involved in housing through SEDC which operates like private housing developers but at the same time fulfilling objectives outlined by the state [26]. This can be seen through the contribution of PKNS in providing and delivering affordable house and involvement of other private sector. To simplify, this three-tier governments play their roles toward approval procedure of the various stages of the housing development process in order to ensure a smooth progress of the project [12]. Therefore, the efficiency of the delivery system will depend on their speed and timely handling of application and issuance of approvals [33]. Meanwhile, housing development includes the role of private developers. In the delivery system, developers are usually responsible in ensuring the project is well marketed and the units are sold, as well as making sure that all the necessary submission were carried out through the assigning of professional consultants and engaging the builders or contractors to undertake project construction [12]. Meanwhile, the professionals involved in the delivery are town planners, architects, surveyors, engineers, landscape designers, etc.

\section{Results and Discussion}

Housing delivery comprises of a process and players involved in the development [12]. Basically, housing development process encompasses of the three major stages known as; (i) pre-development stage; (ii) construction stage; and (iii) post construction stage [34, 9]. The housing delivery process is a typical development process in which it will undergo several stages. The flow of activities or process starting from the inception right up to the delivery of a completed property plays a fundamental role in the planning of a property development [34]. Figure 2 below shows the housing development process currently practiced in Malaysia.

The first stage is the planning stage or the predevelopment period [34]. Housing project begins with land acquisition and ends with selling of the house. During the first stage of housing development, the applicants or housing developers acquire a land and if the acquired land use is under a different category, the developer has to convert the category of land by submitting an application to the relevant land office for a change of land use [11]. Before acquisition of property, the process may start with a feasibility study [12]. Developers will then make an appointment or liaison with consultant(s) [9]. The housing development applications will also go through land approval process as enacted in the Malaysia Land Code, 1965 (Act 56) [35]. 


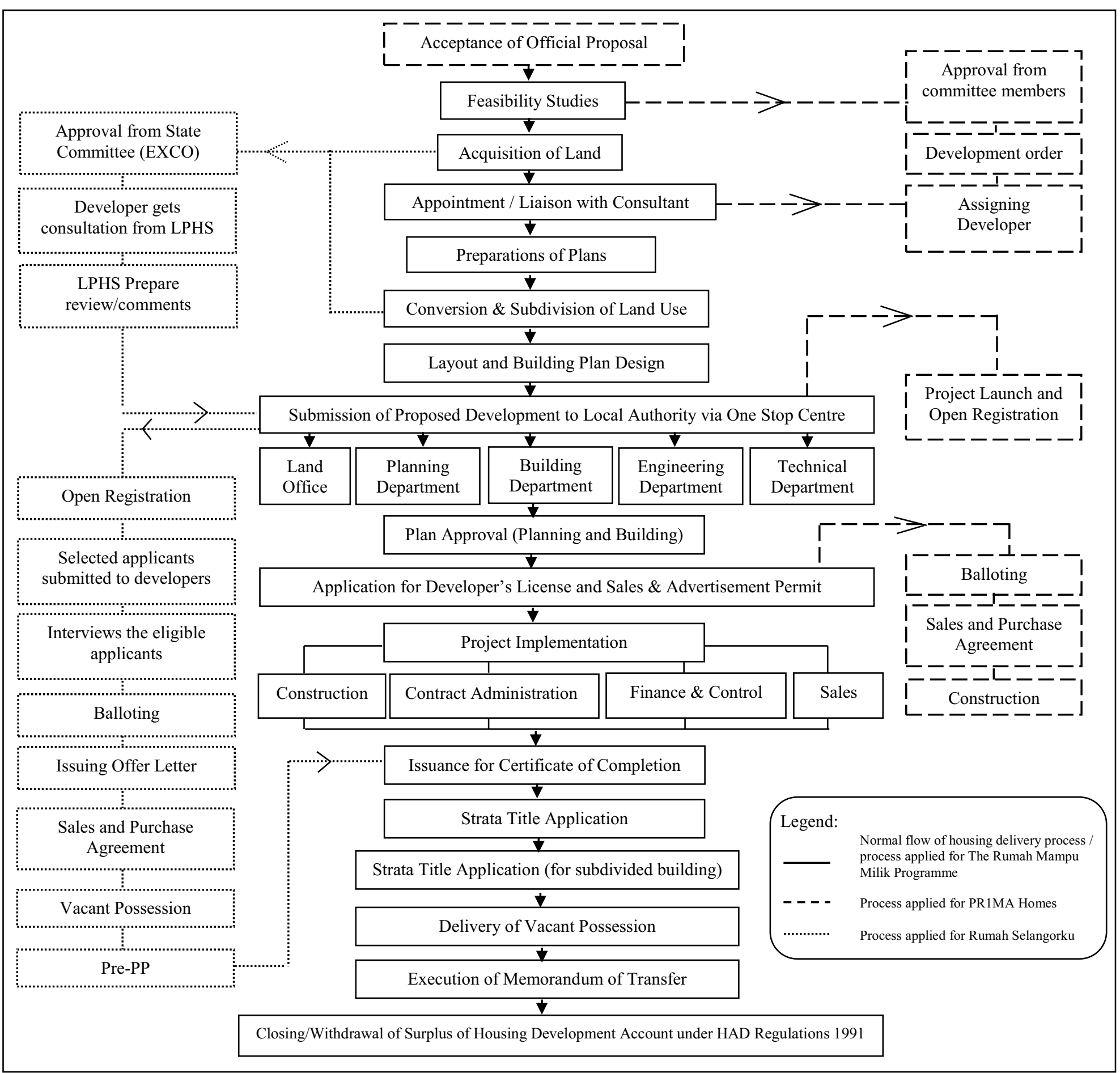

Figure 2: Procedures of affordable housing

Source: Adapted from Hamdan [12]; REHDA [9]; Yaakob et al. [11]; PRIMA [29]; LPHS [32]

Consequently, the developer has to obtain all planning approvals before any physical work can commence on the site and prior to issuance of any advertisement permit by the relevant authorities [34]. Layout and building plans, road plan, infrastructure and other plans are prepared by the consultants with reference to the proposed housing development project [11]. All plans and report prepared by the consultant will be submitted to the One Stop Centre (OSC) of the relevant local authority for the development area [11]. This stage requires planning approval from the local authorities. Planning approval - will therefore involve departments such as land office, planning, building, engineer, and other technical departments $[9,12]$. Through this process, the OSC has indirectly, improved the fragmented and bureaucratic housing approval system at the local level [36]. According to Foo and Wong [36], OSC aimed to speed up the circulation of documents among both internal and external approving departments. Thereafter, developers must send application of license, sales and permit for advertisement from the NHD [9, 12]. When all of the required approvals have been obtained, the construction 
phase will begin [34]. After the layout has been approved by the local planning authority, construction work, such as earthwork and land levelling will start [11]. Construction stage usually will take 24 or 36 months [9]. During project implementation, the construction will be carried out, as well as the administration contract, finance and marketing [9, 11, 12]. After the construction has been completed, a Certificate of Completion and Compliance (CCC) is issued [9, 11, 12, 34]. For subdivided building, a strata title is required [9]. This is followed by the release of vacant possession and follow by the execution of Memorandum of Transfer before closing or withdrawing all money in housing development accounts [9]. The close of a development project or the post development stage is when the completed property is handed over to the owner as required and stipulated by the Housing Development Act. And finally the house key will be handover to the house buyers.

During the interview session, the study found that process of affordable house delivery by SPNB is the same as practiced by other private developers [31]. Meanwhile, the whole projected delivery process for PR1MA homes as practiced by PR1MA can be seen through Figure 3. At the beginning, a review will be carried out to evaluate the project. Hence, a field study or site visit will be carried out to determine the suitability of location for affordable housing development. During this stage, the committee will give their opinion and assessment regarding the whole project such as location, demand area and etc. Once the committee has approved the proposal, the housing proposal project will be presented to the Members of PR1MA Corporation. After that, PR1MA will submit an application to get planning and building approval. In addition, once the application of development has been submitted, PR1MA will start to launch the project through their official website and inform to the public of the project for launching. During this time, the public will start to register for the application of PR1MA homes.
Once the building and planning approval is approved by the local authority, PR1MA will then open the balloting process, licenses and advertising the permit and etc. It will then start the project and incorporate the work of marketing, selling, promotion, application for developers. PR1MA will therefore carry out the balloting process to the potential buyers and there will be an audit responsible for official inspection toward the registrant. Because of that, construction will only start after obtaining planning and building approvals. Finally, PR1MA home will be ready for end-users.

For Rumah Selangorku, basically there are two main agencies in handling this program; either from LPHS as the provider or delivered by the developers while the LPHS acts as the regulator. The approach is demonstrated in Figure 4. Developers are basically aware of the location of land that suits the development. Developers attend to LPHS to acquire comments or agreements in order to determine the types and requirements of Rumah Selangorku. Later, LPHS will issue comments regarding types and percentage in providing affordable houses. Consequently, the applicant (developer) submits the proposal to OSC. There are many agencies involve including the land administrator office, planning, building, engineer and technical departments. All departments will provide their comments to the OSC and an OSC committee meeting will then be carried out. During the meeting, LPHS will be invited as a member based on its roles. OSC will later provide an endorsement letter to the certified agencies, and announce the conditional planning approval to solve the land matters to the State Land Administrator, whilst issuing notification to the successful applicants to the council. Meanwhile, LPHS will also issue a notification letter to the applicants, and OSC will proceed with approval copies to LPHS for the purpose of monitoring. Finally, OSC will collect the approval letters, and hand them over to the applicants.

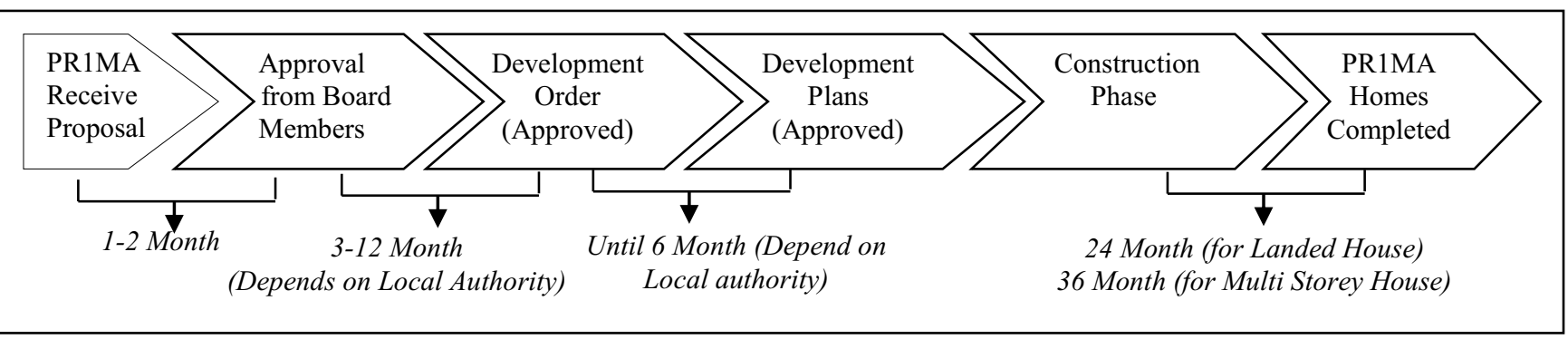

Figure 3: The process for PR1MA homes development Source: PRIMA [29]

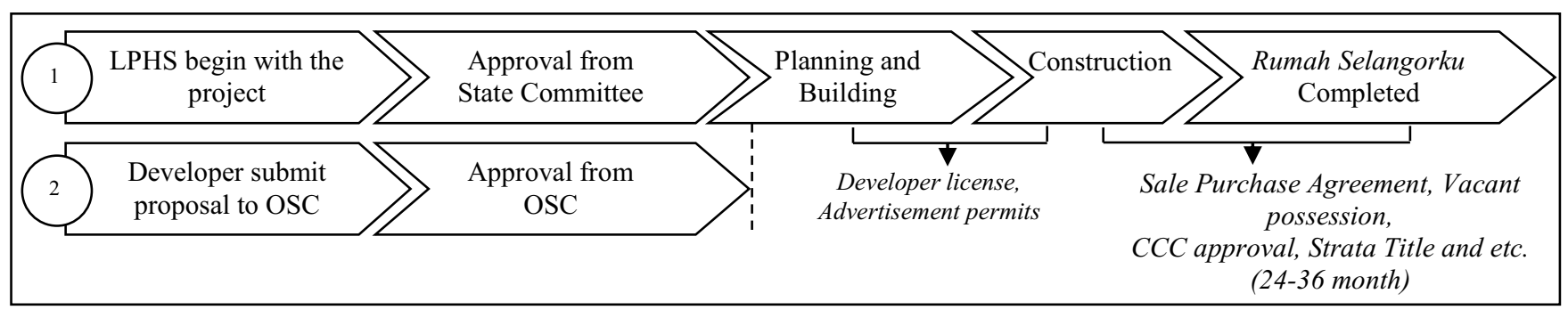

Figure 4: The development process for Rumah Selangorku Source: LPHS [32] 
The following findings were identified based on the review of the providers.

(a) Inconsistency of definition and prices for affordable housing

The prices for affordable housing were not consistent between provider agencies. National Housing Department has defined affordable house below the price of RM300,000. However, each agency which is responsible in providing affordable homes has their own prices in selling affordable homes. This causes inconsistency of affordable housing price. This is also due to the function and purpose of the agencies. Even though the National Housing Department had already outlined the price for affordable house, agencies in providing affordable house also consider the location factor, availability of land, and the local socioeconomic in determining the price of a unit.

(b) Involvement of multiple agencies in providing affordable house

There are various agencies involved in providing affordable house. The main agencies are the NHD, Prima Corporation, and SPNB. Moreover, the state government also develop their own affordable housing program. In certain cases, local level is also responsible in providing affordable house as can be seen through the provision of Rumah Mampu Milik Wilayah Persekututan (RUMAWIP) provided by Kuala Lumpur City Hall (DBKL). And because there are many agencies as providers, this has resulted in the lack of integration for delivery. Therefore, good coordination between agencies such as the creation of integrated database system is necessary to increase the supply and delivery of affordable house.

(c) The effectiveness in delivering affordable house

In a housing development process, a lot of time is required to obtain approval as it involves approval at every stage of the process, including conversion of land use category, delay in getting approval, non-compliance with development plan, infrastructure improvement which increased the production cost and others. Therefore, its affects the whole approval process thus delaying the delivery process. There may not be much difference in the delivery process. But there are some variances between a typical housing development process practiced by private developers and agencies that were appointed by the government such as PR1MA. This can be seen through the system called the balloting process.

\section{Recommendation and Conclusion}

To strengthen the delivery of affordable housing in Malaysia and improve the delivery system practiced by the agencies, there must be a clear definition regarding affordable housing in Malaysia because it may differs for each individual or income group. Affordable houses should be built within the people's affordability which focuses on low and medium-income groups. Moreover, government should revise the ceiling price for affordable house. Affordable housing delivery system should be under one roof, instead of operating separately. A central housing delivery centre would help to rationalise the delivery system of affordable housing. To enhance the system, a single entity to design, build and manage the affordable housing development may decrease the overlapping of role in providing affordable house. Additionally, all of the related authorities should be merged. A clear, separate or shared responsibilities amongst the 3-tier of government in providing affordable housing is crucial. Therefore, this study is hoped to further contribute towards the understanding of the provision of affordable housing in Malaysia through its delivery practice in order to assist homeownership to have home that can be accessed and afforded by the various levels of citizens. The long terms benefits of this study can be seen through theoretical or practical aspects. It can be a helpful reference to the government and related private sectors, especially with regards to the delivery of affordable housing. It can assist other scholars in providing the current scenario and therefore contributing inputs to existing knowledge in terms of affordable housing delivery system. Likewise, future study may emphasis on the potential of a central agency or a model to shorten the duration of delivery that would help to enhance the system.

\section{Acknowledgements}

The authors would like to thank the Ministry of Higher Education, Malaysia for funding the study through the FRGS grant with the project code 600-RMI/FRGS 5/3 (73/2014) and also would like to thank the Universiti Teknologi MARA (UiTM), specifically, the Research Management Centre (RMC) for supporting and managing this grant.

\section{References}

1. The Ministry of Federal Territory, Dasar Rumah Mampu Milik Wilayah Persekutuan. Kuala Lumpur: The Ministry of Federal Territory (2013)

2. I.S. Grewal, Malaysia's Middle Class Challenge: Making Progress. The Star Online. Retrieved from http://www.thestar.com.my (2014)

3. I.Turok and G.M. Granahan, Urbanization and Economic Growth: The Arguments and Evidence for Africa and Asia. SAGE Journals 25, 465-482 (2013)

4. National Housing Department, National Housing Policy. Kuala Lumpur: The Ministry of Housing and Local Goverment (2011)

5. Economic Planning Unit, Rancangan Malaysia Kesebelas: Kertas Strategi 6. Retrieved from http://rmk11.epu.gov.my/pdf/kertasstrategi/Kertas $\% 2$ 0Strategi\%2006.pdf (2015)

6. Institute of Strategic and International Studies (ISIS) Malaysia, ISIS Roundtable: Providing Public and Affordable Housing for Malaysia. Retrieved from www.isis.org.my/files/IF_2013/IF3_2013.pdf (2013)

7. N.M. Malek, and A. Husin, Pemilikan Rumah dalam Kalangan Masyarakat Bandar Berpendapatan Sederhana dan Rendah di Malaysia. Sosiohumanika 5 (2012) 
8. Economic Planning Unit, Rancangan Malaysia Kesebelas, 2016-2020: Kerangka Agenda: Aspirasi Kerajaan dalam Merumahkan Rakyat. Presented at Program City Talk @ Bukit Tinggi 2015 11 November (2015)

9. REHDA, The Housing Delivery System in Malaysia: Opportunities and Challenges. Retrieved from http://www.housingfinance2014.org/fileadmin/2014/ Presentations_English/5_1_Michael_Yam_English.p df (2014)

10. A. Husin, N.M. Malek, and S.A. Gapor, Trends Problems and Needs of Urban Housing in Malaysia. World Academy of Science, Engineering and Technology 74, 1103-1107 (2011)

11. H. Yaakob, F. Yusof, and H. Hamdan, Land Use Regulations towards a Sustainable Urban Housing: Klang Valley Conurbation. Procedia Social and Behavioral Sciences 68, 578-589 (2012)

12. H. Hamdan, Housing Delivery System. Universiti Teknologi MARA (UiTM) Shah Alam. (Unpublished)

13. A. Mustafa, and M. Ghazali, Issues in Housing Delivery Systems and Customer Satisfaction. Elixir Marketing Mgmt 48, 9395-9399 (2012)

14. A. Ghanarajah, Housing Delivery System: Issues and Legal Perspectives. In Housing the Nation: A Definite Study, Kuala Lumpur: Cagamas Berhad, 603-612 (1997)

15. O.O. Makinde, Housing Delivery System: Need and Demand. Environ Dev Sustain 15, 49-69 (2014)

16. A.A. Khalaf, Key Constraint to Improving the Affordable Housing Delivery Process in the Syrian Market: The Potential of Procurement Efficiency. Proceeding of CIB W070,WO92 and TG72 International Conferences, 329-336 (2012)

17. A. Sivam, D. Evans, R. King, and D.Young, An Approach to Improved Housing Delivery in Large Cities of Less Developed Countries. Habitat International 25, 99-113 (2001)

18. Selangor Department of Town and Regional Planning, Draf Rancangan Struktur Negeri selangor 2035. Retrived from http://eps. mbpj. gov. my/web2015/Draf_RSN_2035.pdf (2015)

19. Economic Planning Unit, The Third Malaysia Plan 1976-1980. Retrieved from http://www. epu. gov. my/third-malaysia-plan-1976-1980 (1975)

20. Economic Planning Unit, The Fourth Malaysia Plan 1981-1985. Retrieved from http://www. epu. gov. my/fourth-malaysia-plan-1981-1985 (1980)

21. Economic Planning Unit, The Fifth Malaysia Plan 1986-1990. Retrieved from http://www. epu. gov. my/fifth-malaysia-plan-1986-1990 (1985)

22. Economic Planning Unit, The Sixth Malaysia Plan 1991-1995. Retrieved from http://www. epu. gov. my/sixth-malaysia-plan-1991-1995 (1990).

23. Economic Planning Unit, The Seventh Malaysia Plan 1996-2000. Retrieved from http://www. epu. gov. my/seventh-malaysia-plan-1996-2000 (1995)

24. Economic Planning Unit, The Eight Malaysia Plan 2001-2005. Retrieved from http://www. epu. gov. my/eight-malaysia-plan-2001-2005 (2000)
25. S. Shuid, Low income housing allocation system in Malaysia: managing housing need for the poor. In: 22nd International Housing Research Conference, 4 7, July 2010, Istanbul, Turkey (2010)

26. S. Shuid, The changing role of the state and market in low cost housing provision in Malaysia. Journal of Architecture, Planning and Construction Management 1, 39-70 (2011)

27. National Housing Department, Maklumat Korporat bahagian dan unit. Retrieved from https://ehome. kpkt. gov. my (2015)

28. National Housing Department, My Home Scheme. Retrieved from https://myhome.kpkt.gov.my (2015)

29. PR1MA Corporation, Laporan Kemajuan 20122014. PR1MA Corporation,Kuala Lumpur:Author. (2014)

30. Department of Information, Program Rumah Mampu Milik. Retrieved from http://pmr. penerangan. gov. my/index. $\quad$ php/umum/12252--program-rumahmampu-milik.html (2008)

31. Syarikat Perumahan Negara Berhad, Official website. Retrieved from http://www.spnbaspirasi.com.my (2014)

32. Lembaga Peumahan dan Hartanah Selangor,Rumah Selangorku City Talk@Bukit Tinggi 2015. 11-12 November 2015 (2015)

33. L. Chan, Housing delivery system: The industry viewpoint. In Housing the Nation: A definite Study Kuala lumpur : Cagamas Berhad, 603-612 (1997)

34. A.A. Abdullah, Z. Harun, and H.A Rahman, Planning process of developement in the Malaysian context: A crucial brief overview. Internatioal Journal of Applied Science and Technology 1 (2011)

35. A. Rameli, F. Johar, and H.C. Siong, Responsiveness to the market mechanisms: A way to strengthen the Malaysian housing planning process. Jurnal Alam Bina 9, 1-22 (2007)

36. L. H. R. Foo, and C. Wong, Planning for housing developemnts in Malaysia: Developer's response to the regulatory policy framework. International Planning Studies 19, 192-209 (2014) 